\title{
Saccharopolyspora hirsuta strain 367 releases JHJ-1, a bacteriophage capable of propagation on old mycelium
}

\author{
Jacques Haket, Jr, Danielle Desmarais, Khalil Mehindate and Claude V. Déry* \\ Département de Biologie, Faculté des Sciences, Université de Sherbrooke, Sherbrooke (Québec) J1K 2R1, Canada
}

(Received 4 September 1989; revised 14 November 1989; accepted 24 November 1989)

\begin{abstract}
Bacteriophage JHJ-1 was isolated from Saccharopolyspora hirsuta strain 367 NRRL 12045 as an endogenous but virulent phage. The plaque size was not self-limiting, since a few p.f.u. could completely lyse a lawn. Electron microscopy showed that this phage belonged to group B of Bradley's morphological classification. The JHJ-1 genome is a linear DNA molecule of $41.1 \mathrm{kbp}$ with cohesive ends and a $G+C$ content of $68.8-70.0 \mathrm{~mol} \%$. The DNA cleavage map was established for 12 restriction endonucleases. The host range is apparently very narrow, being limited to two strains of S. hirsuta (NRRL 12045 and NRRL B-5792). However, JHJ-1 did not lytically infect $S$. hirsute strain 367 UC 8106. Phage JHJ-1 was shown, by Southern blot analysis, to lysogenize both $S$. hirsuta NRRL 12045 and UC 8106. It thus appears to behave as a virulent mutant of a temperate phage on one, but not on the other, JHJ-1 lysogen.
\end{abstract}

\section{Introduction}

A large number of bacteriophages have been isolated from actinomycetes. These phages are known to decrease the yield of antibiotics and other metabolites during the fermentation process (Ogata, 1980; Chater, 1986). Actinomycete phages have also been used as models for the study of cellular regulatory mechanisms and for the development of cloning vectors (for reviews, see Chater, 1986; Lomovskaya et al., 1980).

Saccharopolyspora hirsuta 367 is the producer of nodusmicin, a typical macrolide antibiotic (Whaley et al., 1980). During the course of our experiments on $S$. hirsuta 367 NRRL 12045, a phage, JHJ-1, endogenous to this strain was isolated. Its morphology, host range, genome and intracellular state are described here. This phage exhibits two interesting features: the formation of plaques on some, but not all, strains carrying it as a prophage; and the ability of plaques to continue growth for many days.

\section{Methods}

Strains. S. hirsuta strains referred to as 12045 , UC 8106 and IC-11 are all versions of the original isolate strain 367 (Whaley et al., 1980): 12045 was obtained from NRRL; UC 8106 was obtained from the UpJohn Company; and IC-11 was a colony of 12045 that did not release phage (see Results). The independently isolated $S$. hirsuta NRRL B-5792 is the type strain. Other strains were obtained from NRRL, ATCC and the collection of the John Innes Institute (Norwich, UK).
Media, buffers and chemicals. The culture medium W, used for phage titration, amplification and host range experiments, contained $10 \mathrm{~g}$ yeast extract, $0.5 \mathrm{~g} \mathrm{~K}_{2} \mathrm{HPO}_{4}$ and $10 \mathrm{~g}$ D-glucose per litre, and was adjusted to pH 6.5 (Ostrowska-Krysiak et al., 1971). Medium W was used as liquid medium or solidified with $0.8 \%(\mathrm{w} / \mathrm{v})$ (soft agar) or $1.5 \%$ (w/v) (bottom agar) Bacto Agar (Difco). The sporulation medium ATCC no. 5 (SPM) contained $1.0 \mathrm{~g}$ yeast extract, $1.0 \mathrm{~g}$ beef extract, $2.0 \mathrm{~g}$ tryptose, $10 \mathrm{~g}$ glucose, $15 \mathrm{~g}$ agar and a trace of $\mathrm{FeSO}_{4}$ per litre. The phage buffer contained $50 \mathrm{~mm}-\mathrm{Tris} / \mathrm{HCl} \mathrm{pH} 7.5,10 \mathrm{~mm}-\mathrm{Ca}\left(\mathrm{NO}_{3}\right)_{2}$ and $10 \mathrm{mM}^{-\mathrm{MgSO}_{4}}$ (Smorawinska et al., 1988). Restriction enzymes, Bal-31 exonuclease, T4 DNA ligase and the Klenow fragment of the DNA polymerase I of Escherichia coli were obtained from Boehringer Mannheim Biochemicals or New England Biolabs and were used in accordance with the manufacturer's recommendations.

Virus titration, amplification and purification. $\mathrm{JHJ}-1$ was titrated and amplified on plates with a lawn of IC-11, using the double-layer technique (Adams, 1959). For large-scale amplification, twenty $10 \mathrm{~cm}$ plates were routinely used: approximately $10^{3}$ p.f.u. of $\mathrm{JHJ}-1$ were mixed with $0.3 \mathrm{ml}$ of a dense liquid mycelial culture of IC- 11 in a $4 \mathrm{ml}$ soft agar supplemented with $10 \mathrm{mM}-\mathrm{MgSO}_{4}$, and overlaid on the bottom agar. For strains UC 8106 and IC-11, liquid mycelial cultures were used since these strains did not sporulate sufficiently to provide a confluent lawn. The plates were incubated at $30^{\circ} \mathrm{C}$ for $3 \mathrm{~d}$, cooled at $4^{\circ} \mathrm{C}$ for $1 \mathrm{~h}$, and flooded with $5 \mathrm{ml}$ of phage buffer containing 2-3 drops of chloroform. After $8 \mathrm{~h}$ at $4{ }^{\circ} \mathrm{C}$, the phage lysate was harvested and centrifuged at $4{ }^{\circ} \mathrm{C}$ for $15 \mathrm{~min}$ at $4000 \mathrm{~g}$. The supernatant was collected and adjusted to $0.5 \mathrm{M}-\mathrm{NaCl}$ and $10 \%(\mathrm{w} / \mathrm{v})$ PEG 8000 (Yamamoto $e t$ al., 1970). After at least $4 \mathrm{~h}$ at $4{ }^{\circ} \mathrm{C}$, the suspension was centrifuged as described above. The pellet was then resuspended in phage buffer and layered over a $\mathrm{CsCl}$ step gradient. The gradient was made from three $2 \mathrm{ml}$ solutions with densities of $1.360,1.490$ and $1.600 \mathrm{~g} \mathrm{~cm}^{-3}$ in phage buffer. The gradients were centrifuged at 30000 r.p.m. for $3 \mathrm{~h}$ at $16^{\circ} \mathrm{C}$ in a SW 41 rotor (Smorawinska et al., 1988). The phage banded at the 1.490 and 1.600 interface and was harvested by puncturing the side of the tube. The phage suspension was maintained at $4{ }^{\circ} \mathrm{C}$ in this solution 
and the phage yield averaged $10^{11}-10^{12}$ p.f.u. Such phage suspensions were stable for at least 12 months.

Determination of the host range. For rapid determination of the host range of phage $\mathrm{JHJ}-1,10 \mu \mathrm{l}$ of a $\mathrm{CsCl}$-purified phage suspension was spotted on a lawn of mycelial culture or heat shocked $\left(10 \mathrm{~min}, 55^{\circ} \mathrm{C}\right)$ spores $\left(10^{7}\right.$ c.f.u.) of each strain (Grund \& Hutchinson, 1987). The plates were incubated at $30^{\circ} \mathrm{C}$, except for Faenia rectivirgula, which was incubated at $43^{\circ} \mathrm{C}$ (Smorawinska et al., 1988), and examined daily for up to $10 \mathrm{~d}$ for evidence of lysis. For a few strains, the virus stocks were diluted to allow visualization of isolated plaques.

Extraction and characterization of JHJ-I DNA. CsCl-purified phage particles were dialysed against phage buffer. The suspension was then treated with DNAase and RNAase (Sigma), both at a final concentration of $50 \mu \mathrm{g} \mathrm{ml}^{-1}$, for $1 \mathrm{~h}$ at $37^{\circ} \mathrm{C}$. Proteinase $\mathrm{K}(0 \cdot 1 \mathrm{mg}$ $\mathrm{ml}^{-1}$ ) and SDS (final concentration, $0.5 \%$ ) were then added. After incubation for $1 \mathrm{~h}$ at $37^{\circ} \mathrm{C}$, the viral DNA was purified by extraction with phenol, phenol/chloroform and chloroform/isoamyl alcohol (24:1, $\mathrm{v} / \mathrm{v}$ ). The DNA was recovered by ethanol precipitation, dried under vacuum and resuspended in TE buffer ( $10 \mathrm{mM}$-Tris/ $\mathrm{HCl}, 1 \mathrm{mM}$-EDTA, pH 8.0).

Actinomycete DNA was purified as described by Hopwood et al. (1985).

Agarose gel electrophoresis was performed in Tris/borate/EDTA (TBE) buffer with agarose concentrations varying from 0.5 to $1.2 \%$ $(w / v)$. The gels were stained with ethidium bromide $\left(1 \mu \mathrm{g} \mathrm{ml}^{-1}\right.$, final concentration) and photographed (Maniatis et al., 1982).

The $\mathrm{mol} \% \mathrm{G}+\mathrm{C}$ content was determined by the ultraviolet spectroscopic method of Ulitzur (1972) and by the $\mathrm{CsCl}$ density gradient analysis of Mandel et al. (1968) as modified by Robin \& Rodrigue (1980), except that the peaks of DNA in the gradient were localized by spotting $1 \mu \mathrm{l}$ of each fraction on an agarose gel containing $1 \mu \mathrm{g}$ ethidium bromide $\mathrm{ml}^{-1}$ (Maniatis et al., 1982). For both methods, $E$. coli $\mathrm{K} 12$ DNA (density $1.710 \mathrm{~g} \mathrm{ml}^{-1}$ ) was included as reference standard (Mandel et al., 1968).

Genomic DNA blot analysis. JHJ-1 and S. hirsuta genomic DNA were digested with restriction enzymes and electrophoresed on $0.8 \%$ agarose gels. DNA was transfered to Hybond $\mathbf{N}$ membranes (Amersham) according to the method of Smith \& Summers (1980). DNA probes were labelled with the Multiprime labeling system (Amersham). DNA was hybridized according to the method of Wahl et al. (1979), except that the hybridization and wash temperatures were $52^{\circ} \mathrm{C}$ and $70^{\circ} \mathrm{C}$ respectively, to take account of the $\mathrm{mol} \% \mathrm{G}+\mathrm{C}$ content of $\mathrm{JHJ}-1$ DNA.

Electron microscopy. Carbon-coated grids ( 300 mesh) were positively charged by treatment with $1 \%(\mathrm{w} / \mathrm{v})$ Alcian Blue for $5 \mathrm{~min}$. Dialysed phage particles $\left(10^{9}\right.$ p.f.u. $\left.\mathrm{ml}^{-1}\right)$ were adsorbed for $1 \mathrm{~min}$ and stained for $30 \mathrm{~s}$ with $2 \%(\mathrm{w} / \mathrm{v})$ uranyl acetate or $2 \%(\mathrm{w} / \mathrm{v})$ phosphotungstic acid, pH 7.1. The grids were examined in a Philips 201 electron microscope. The magnification was calibrated using a carbon grating replica.

\section{Results}

\section{Strain 12045 spontaneously releases bacteriophage JHJ-1}

We originally obtained a culture of $S$. hirsuta strain 367 from NRRL (NRRL 12045). After the second cycle of growth and sporulation, plaques appeared $2 \mathrm{~d}$ after plating a dense mycelial culture on SPM. In order to obtain an indicator strain for phage propagation, we isolated, by plating dilutions of a mycelial culture of strain 12045 on medium W, a colony named IC-11 that showed no plaque formation after amplification in liquid medium W, replating at high density on SPM or medium $\mathrm{W}$ and incubation for $5 \mathrm{~d}$. At this point, strain IC-11 was assumed not to carry extracellular phages nor to spontaneously release phages. However, mock-infected plates were always used for each experiment involving this strain (titration, amplification). The chromosomal DNA of IC-11 was identical to that of 12045 as judged by their restriction patterns (data not shown). Strain IC-11 was used to amplify one plaque to demonstrate the presence of a bacteriophage, which was isolated and named JHJ-1. Nine phage DNA preparations isolated from other plaques appearing on 12045 were identical to JHJ-1 DNA by restriction mapping.

Since strain 12045 released a bacteriophage, the frequency of the phenomenon was briefly investigated. Strain UC 8106 and 16 colonies resulting from spores of 12045 (see later) never showed spontaneous plaque formation when mycelial cultures were plated at high density and incubated for up to 2 weeks, whereas under the same conditions, IC-11 occasionally showed spontaneous clear plaque formation after 8-10 d. The phage DNA isolated from three of these plaques was identical to that of JHJ-1 as determined by restriction mapping. No phage were detected when culture supernatants of IC- 11 or UC 8106 were plated on IC- 11 or B-5792 as indicator strains. However, B-5792 is not a sensitive indicator strain since evidence of restriction was found in this strain (see later).

\section{Plaque and phage morphology}

When JHJ-1 was grown on a lawn of strain IC-11, the plaques were clear with a diameter of 3-4 mm after $2 \mathrm{~d}$ incubation. However, when such plates were incubated for longer periods, the diameter of the plaques increased. In fact, 10 plaques (diameter 3-4 mm after $2 \mathrm{~d}$ ) completely lysed the lawn after incubation for 2-3 weeks. This effect was also observed on YEME (Hopwood et al., 1985), Tryptic Soy Agar (Difco) and SPM. This contrasts with the self-limiting plaque size observed with most, if not all, bacteriophages described thus far.

Phage JHJ-1 has a binal symmetry, with an icosahedral head and a long flexible and striated tail (Fig. 1). The tail $(170 \mathrm{~nm})$ is more than three times longer than the head $(50 \mathrm{~nm})$. In some particles, a possible part of the channel mediating DNA injection into the host was observed (Fig. 1c). When the virions were stained with phosphotungstic acid, three structures resembling spikes at the end of the tails were observed (Fig. 1c). Such structures have been recorded in other actinophages (Berthiaume \& Ackermann, 1977) and, accordingly, phage $\mathrm{JHJ}-1$ is classified as a member of morphological 


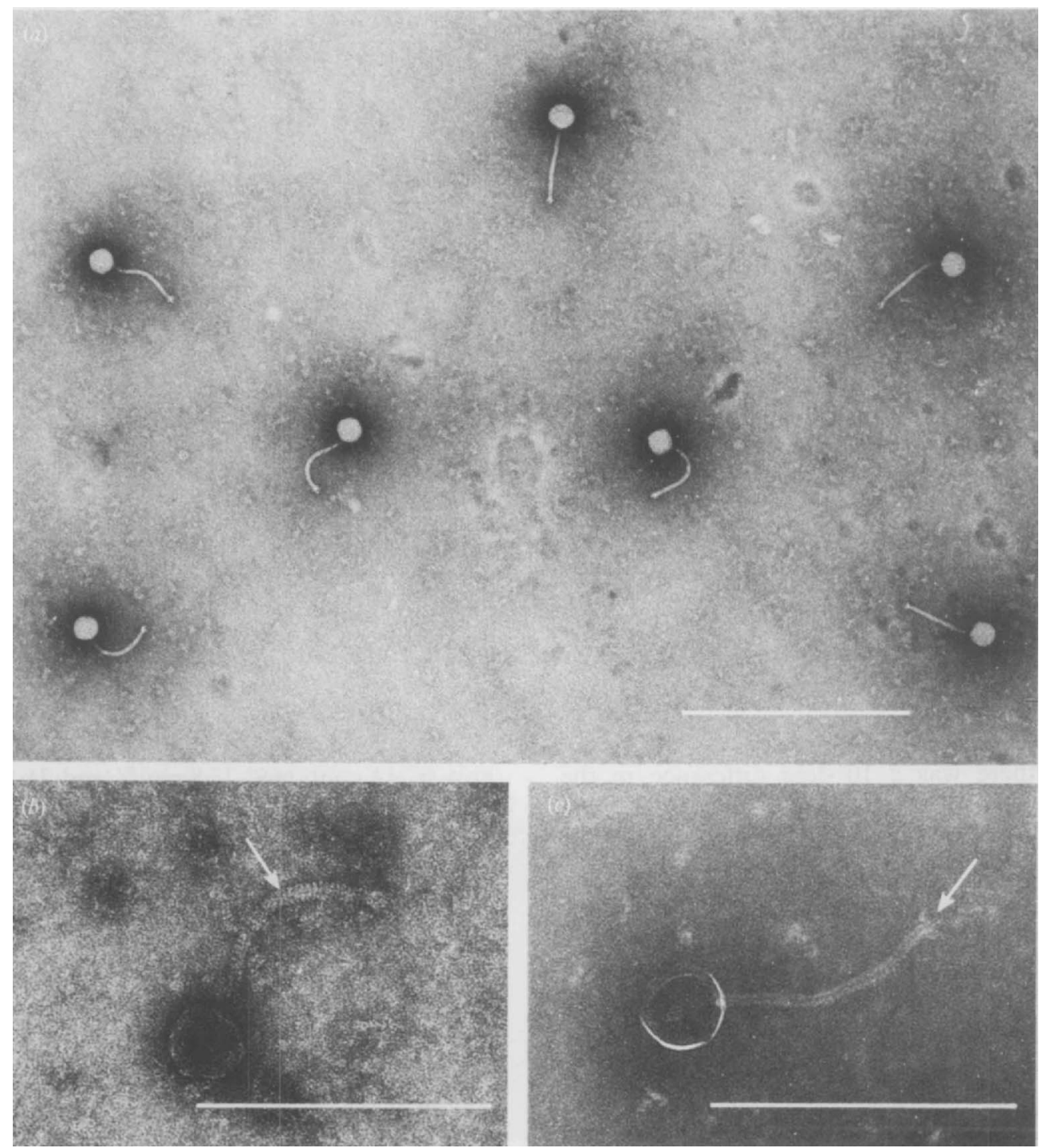

Fig. 1. Electron micrographs of JHJ-1 virions. $\mathrm{CsCl}$-purified virions were adsorbed on the grids and stained with uranyl acetate $(b)$ or phosphotungstic acid $(a, c)$. The arrows show the striated tail $(b)$ and the spikes at the end of the tail $(c)$. The bars represent $0.5 \mu \mathrm{m}$ (a) and $0.2 \mu \mathrm{m}(b, c)$.

group B (Bradley, 1967), characterized by an isometric head, a hexagonal shape, and a very long non-contractile tail. In this group, the tail is often striated and may possess a terminal bulb.

\section{Host range of phage $\mathrm{JHJ}-1$}

$S$. hirsuta strain 367 belongs to a genus which comprises only two species, $S$. hirsuta and $S$. erythraea; $S$. hirsuta NRRL B-5792 is the type strain of the species (Lacey \& Goodfellow, 1975). In order to determine the host range of phage JHJ-1, particles were spotted on lawns of mycelium of UC 8106 and B-5792 and on lawns of heatshocked spores of B-5792 and three $S$. erythraea strains
(NRRL 2360, ISP 5517 and NRRL 2359). Only $S$. hirsuta NRRL B-5792 exhibited lysis of the lawn, on preparations both from mycelium and from heatshocked spores. No evidence of lysis was visible with UC 8106, even at $10^{10}$ p.f.u. per plate. Since strains NRRL 12045 and UC 8106 have the same DNA restriction patterns, UC 8106 would be expected to be sensitive to infection by JHJ-1. Strain UC 8106 may be a phage-resistant isolate of the culture sent to NRRL by the UpJohn Co. However, B-5792 exhibited a DNA restriction pattern completely different from both UC 8106 and IC-11 (data not shown), and S. hirsuta strain 367 may therefore represent a different Saccharopolyspora species. There was evidence of restriction in 

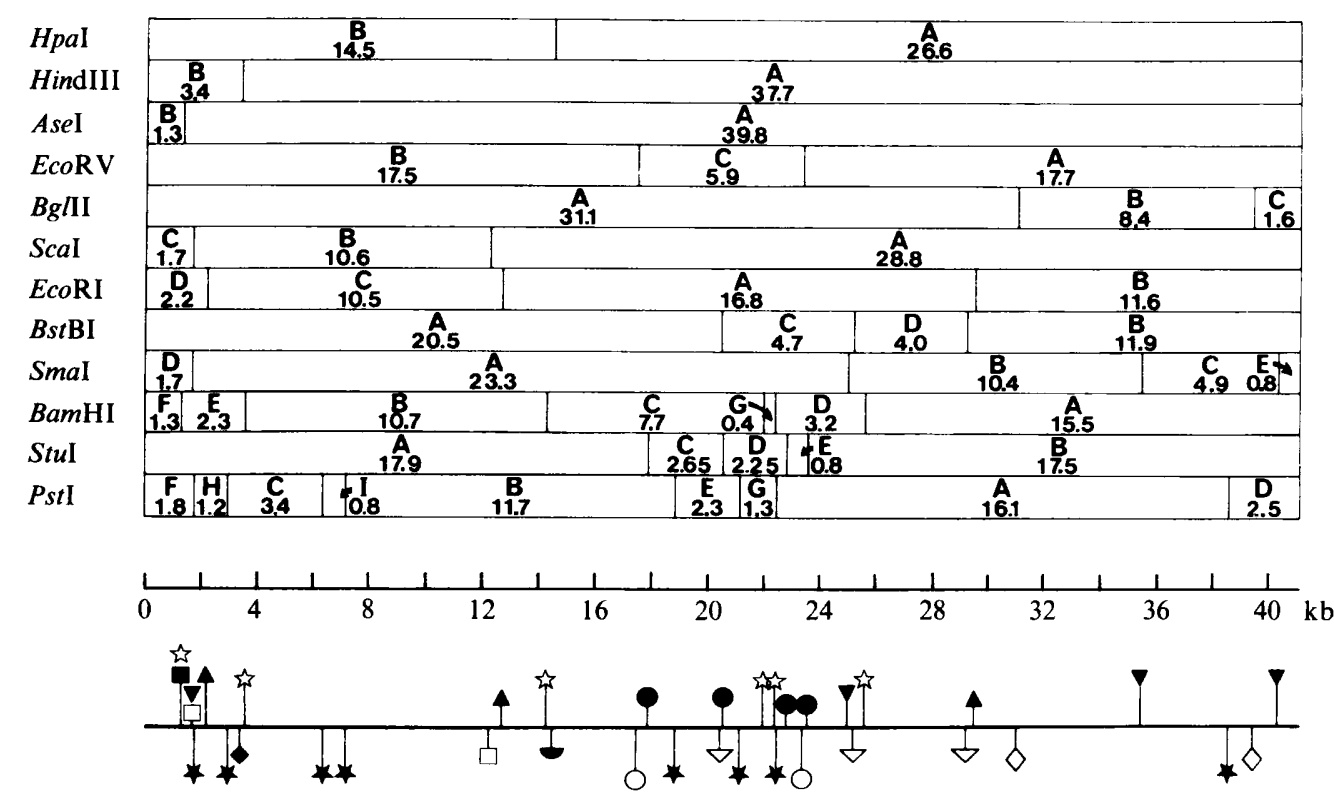

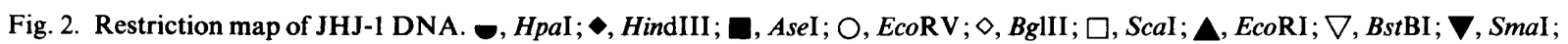
, StuI; Ł, BamHI; $\star$, PstI.

B-5792, since there was a $10^{4}$-fold difference in the plating efficiency on B-5792 and IC-11 of JHJ-1 grown in IC-11, yet JHJ-1 grown on B-5792 plated equally well on both B-5792 and IC-11. No plaque or clearing effects were visible on the $S$. erythraea strains, even after $10 \mathrm{~d}$ incubation.

Seven Streptomyces strains, namely Strep. lividans TK24 (John Innes Institute collection), Strep. labedae NRRL B-5616 (formerly Strep. erythraeus) (Lacey, 1987), Strep. avermitilis NRRL 8165, Strep. clavuligerus ATCC 27064, Strep. coelicolor A(3)2 (John Innes Institute collection) and Strep. albus G wild-type and SalI restriction-defective mutant $\mathrm{J} 1074$ (John Innes Institute Collection), were also refractory to infection by $\mathrm{JHJ}-1$, as were Faenia rectivirgula DSM 43747, Amycolatopsis rugosa NRRL 2295, Saccharothrix aerocolonigenes NRRL B-11267, Micromonospora rosaria NRRL 3718, Actinoplanes caeruleus NRRL 5325, Streptoverticillium flavopersicum NRRL B-2820 and Nocardia argentinensis ATCC 31306, a producer of nargenicin, an antibiotic similar to nodusmicin (Snyder \& Rinehart, 1984). Plaque assays performed on $S$. hirsuta UC 8106, Strep. lividans TK24, F. rectivirgula, Strep. labedae, and $S$. erythraea NRRL 2360 and NRRL 2359 did not allow visualization of plaques.

\section{Analysis of the DNA of phage JHJ-1}

The $\mathrm{G}+\mathrm{C}$ content of JHJ-1 DNA was $68.8 \mathrm{~mol} \%$ as determined by the buoyant density method. The spectrophotometric method gave $70.0 \mathrm{~mol} \%$. The DNA of the host IC- 11 contained $73.8 \mathrm{~mol} \%$ and $71 \cdot 1 \mathrm{~mol} \% \mathrm{G}+\mathrm{C}$, as determined by the $\mathrm{CsCl}$ buoyant density and the spectrophotometric methods respectively. The genome length of the phage, calculated as the sum of restriction fragments, is $41.1 \mathrm{~kb}$. The genome has cohesive ends, confirmed by three different techniques: labelling of the end with Klenow fragment of DNA polymerase I in the presence of $\left[\alpha^{-32} \mathrm{P}\right] \mathrm{dCTP}$ then digestion with restriction endonuclease; ligation followed by digestion; heating restriction enzyme digests at $90^{\circ} \mathrm{C}$ for $10 \mathrm{~min}$ and cooling on ice before loading on agarose gels (results not shown).

The phage DNA was digested with 31 restriction enzymes (Table 1) and 12 enzymes were chosen for the restriction map (Fig. 2). Maps were deduced from partial digestion, double digestion and Bal-31 exonuclease sequential digestion, and by comparing heated and nonheated restriction digests. In two cases, large fragments (EcoRV A and B; StuI A and B) could not be resolved even on $0.5 \%$ agarose gels. These fragments were arbitrarily placed on the map. Complete digestion by EcoRI, BstBI and SmaI could not be achieved, possibly due to the high $\mathrm{G}+\mathrm{C}$ content of JHJ-1 DNA. It is known that some restriction sites are refractory to digestion by some enzymes (Brown \& Smith, 1977; Gingeras \& Brooks, 1983).

JHJ-1 DNA was not digested by MluI, XbaI or XhoI. In these cases, the phage DNA was co-digested with plasmids having at least one of each restriction site to demonstrate the absence of enzyme inhibitors (data not shown). Genomic DNA of IC-11, B-5792 and UC 8106 
Table 1. Restriction enzymes used to digest JHJ-1 DNA and the numbers of fragments obtained

\begin{tabular}{|c|c|c|c|c|c|}
\hline Enzyme & $\begin{array}{c}\text { No. of } \\
\text { fragments }\end{array}$ & Enzyme & $\begin{array}{c}\text { No. of } \\
\text { fragments }\end{array}$ & Enzyme & $\begin{array}{c}\text { No. of } \\
\text { fragments }\end{array}$ \\
\hline AseI & 2 & HindIII & 2 & SaII* & $>20$ \\
\hline ApaI & $>15$ & HpaI & 2 & ScaI & 3 \\
\hline Bam $\mathrm{HI}^{*}$ & 7 & $K p n I^{*}$ & 9 & SmaI & 5 \\
\hline$B c / I^{*}$ & 11 & $M l u \mathrm{I}$ & 0 & $S p h I^{*}$ & $>10$ \\
\hline$B g I I I$ & 3 & NarI $^{*}$ & $>20$ & Sst $\mathrm{I}^{*}$ & $>13$ \\
\hline BssHII & $>20$ & $N r u I^{*}$ & $>12$ & Sst II * & $>20$ \\
\hline BstBI & 4 & NsiI & 6 & StuI* & 5 \\
\hline BstEII & $>13$ & Pst I $^{*}$ & 9 & $X b a I$ & 0 \\
\hline ClaI & 5 & PvuI* & $>20$ & XhoI* & 0 \\
\hline EcoRI & 4 & PvulI* & $>15$ & $X m n I$ & 6 \\
\hline EcoRV & 3 & & & & \\
\hline
\end{tabular}

* Denotes that isoschizomers of those enzymes were found in actinomycetes (Roberts, 1984).

was resistant to $X b a \mathrm{I}$ and $X h o I$ and was digested by $M l u \mathrm{I}$, suggesting that these strains may encode $\mathrm{XhoI}$ and $\mathrm{XbaI}$ methylase specificity.

\section{Strains UC 8106 and IC-11 carry intracellular phage DNA}

In order to demonstrate the presence of intracellular phage sequences, purified DNA from JHJ-1, UC 8106 and IC-11 was digested with PstI and heat-treated at $90{ }^{\circ} \mathrm{C}$ to denature the cohesive sequences. Equal amounts of the bacterial genomic DNA were electrophoresed with $\mathrm{JHJ}-1$, blotted and hybridized with $\mathrm{JHJ}-1$ genomic DNA or with a plasmid clone containing the fused cohesive $P$ st I fragments $\mathrm{D}(2.5 \mathrm{kbp})$ and $\mathrm{F}(1.8 \mathrm{kbp})$ (Fig. 3). JHJ-1 DNA was present in strains IC-11 (and 12045) and UC 8106 but not in B-5792 (not shown). This DNA was present in an intracellular form, since the 1.8 and $2.5 \mathrm{kbp}$ PstI fragments were fused to give a $4.3 \mathrm{kbp}$ fragment (Fig. 3). However, the sensitivity of IC-11 (or 12045) to phage JHJ-1 could still be due to the presence of lysogenic phage in a small proportion of the bacterial population; this would explain the clear plaques caused by $\mathrm{JHJ}-1$ infection. In order to rule out this possibility, we plated spores of 12045 from our initial stock of spores. Isolated colonies were amplified and analysed for JHJ-1 phage sensitivity and for the presence of intracellular phage DNA. All 16 clones were sensitive to phage JHJ-1, none released any phages and their hybridization patterns were identical to that of IC-11. Therefore JHJ-1 can infect a bacterial strain which contains a resident phage.

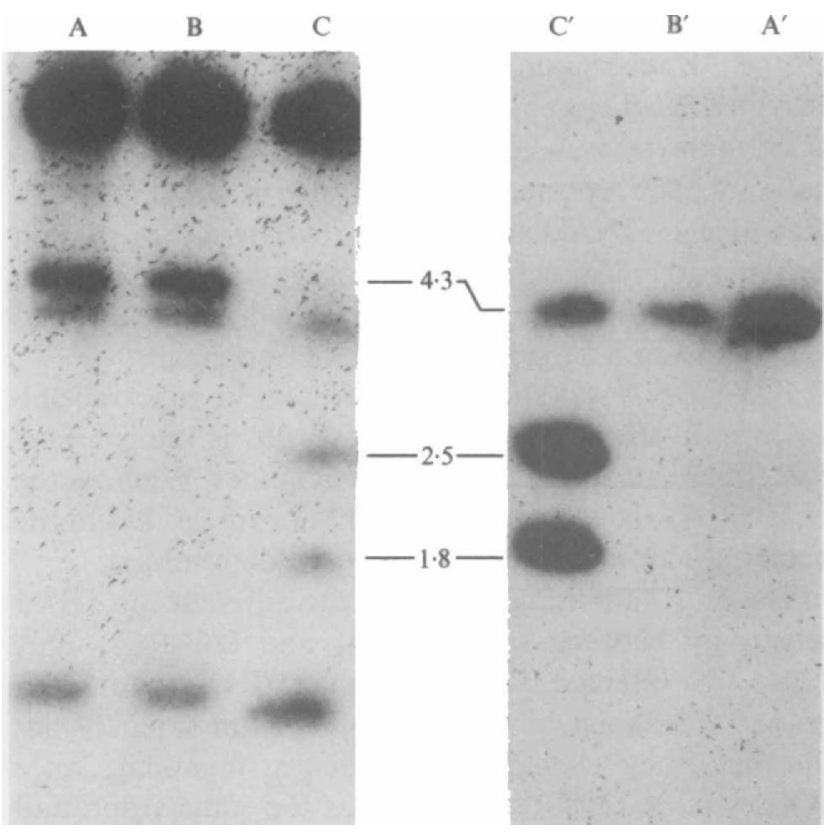

Fig. 3. Pattern of hybridization of IC-11 (A), UC 8106 (B) and JHJ-1 (C) DNA. The DNAs, digested with PstI, were hybridized with phage JHJ-1 DNA (A-C) or a cloned $4.3 \mathrm{kbp}$ fragment containing the cohesive PstI fragments $D$ and $F\left(A^{\prime}-C^{\prime}\right)$. The 1.8 and $2.5 \mathrm{kbp}$ fragments represent the two Pst I cohesive fragments; the $4.3 \mathrm{kbp}$ fragment represent the fused fragments.

\section{Discussion}

Phage $\mathrm{JHJ}-1$ is different from any previously characterized actinophage as judged by its host range, $\mathrm{mol} \%$ $\mathrm{G}+\mathrm{C}$ content, the number of restriction enzyme cleavage sites, and from its restriction map. An intriguing feature of $\mathrm{JHJ}-1$ is its potential to grow on both young and 'aged' cultures. The plaque size is not self-limiting and there was no difference in the titre when the phage was plated on heat-shocked spores or a dense mycelial culture of $S$. hirsuta B-5792. JHJ-1 may be able to exploit the characteristic stationary phase of ageing actinomycete cultures in which the cells, unlike those of dividing bacteria, are continuing to metabolize (Hopwood, 1988).

The host range of JHJ-1 is narrow, limited to only two strains, S. hirsuta NRRL B-5792 and NRRL 12045, among the 19 strains tested. It appears to be characteristic of phages isolated on Saccharopolyspora strains that they have a host range limited to this genus (Katz et al., 1988; Brzezinski et al., 1986; Grund \& Hutchinson, 1987; Donadio et al., 1986). The recent observations that phages P517, 121, SE-3 and SE-5 of S. erythraea can infect Faenia rectivirgula are exceptions (Kempf $e t$ al., 1987; Smorawinska et al., 1988). However, Faenia and Saccharopolyspora are closely related wall type IV actinomycete genera (Embley et al., 1988a, b). 
Phage JHJ-1 DNA was resistant to cleavage by three of the 31 restriction enzymes tested. Of these three enzymes, $\mathrm{XhoI}$ isoschizomers are known to be produced by actinomycetes, whereas $X b a \mathrm{I}$ and $M l u \mathrm{I}$ isoschizomers have not been reported thus far (Roberts, 1984). The fact that JHJ-1 DNA can be restricted by 13 restriction enzymes found in actinomycetes suggests, according to Cox \& Baltz (1984), that the phage has not evolved recently from a broad-host-range actinophage.

JHJ-1 DNA was shown to be present in an intracellular form in strains 12045 and UC 8106, as the cohesive PstI fragments were fused in their genomes. Whether the phage DNA is present as a plasmid or integrated in the bacterial chromosome remains to be determined.

The most surprising result was the difference in JHJ-1 sensitivity between strains 12045 and UC 8106. Only 12045 was infected lytically by phage JHJ-1. However, both strains should be representatives of the same species [in fact, they should be genetically identical, since Whaley et al. (1980) cited them as the same strain and their restriction patterns were identical] and they are lysogenized by the same phage. Moreover, all the 16 clones isolated from our first spore stock of 12045 were sensitive to $\mathrm{JHJ}-1$ infection and contained intracellular phage DNA. The most obvious explanation would be that JHJ-1 represents a virulent mutant of a lysogenic phage, thus allowing phage $\mathrm{JHJ}-1$ to avoid repression in strain 12045; in this case we believe that the resistance of UC 8106 would be caused by a block during the adsorption of the phage particle or during the early phase of the viral cycle. Alternatively, it is possible that, for unknown reasons, a wild-type JHJ-1 phage could bypass the regulatory circuit of repression of a mutant 12045 . Thus UC 8106 would represent a normal lysogenic strain immune to super-infection by the same phage. However, a phenomenon similar to the Pgl phenotype, a genetically unstable character of Streptomyces coelicolor, might be involved. The $\mathrm{Pgl}^{+}$phenotype causes phage $\phi \mathrm{C} 31$ to be unable to undergo more than one round of lysis in Strep. coelicolor and hence prevents plaque formation, while $\mathrm{Pgl}^{-}$mutants give plaques upon phage infection (Chater, 1986). Thus, UC 8106 would be $\mathrm{Pgl}^{+}$and contain a prophage, and 12045 (and IC-11) would be $\mathrm{Pgl}^{-}$and therefore be sensitive to any virulent mutation that spontaneously occurred during culture maintenance. If UC 8106 was a $\mathrm{Pgl}^{+}$strain, this character would have to be very stable since JHJ-1 never yielded plaques on this strain.

Evidence that $\mathrm{JHJ}-1$ is a virulent mutant of a prophage has been obtained. Following treatment of strains UC 8106 and IC-11 with mitomycin C, culture supernatants yielded turbid plaques of self-limiting size on B-5792 as indicator strain; the induced phages did not yield any plaques on IC-11 (L. R. Gaudreau \& C. V.
Déry, unpublished results). This induced temperate phage is presently being characterized and its properties will be compared with JHJ-1.

We wish to thank the UpJohn Company and Dr A. J. Lyons of NRRL for providing bacterial strains; Ryszard Brzezinski, Brian G. Talbot and François Denis for discussions and critical reading of the manuscript; Dominique Boucher for providing $E$. coli DNA; Gilles Grondin for the electron microscopy analysis and Anne Rousseau for secretarial assistance. Danielle Desmarais is the recipient of a fellowship from the Natural Sciences and Engineering Research Council of Canada (NSERCC). This research was supported by a grant from the NSERCC to C.V.D.

\section{References}

ADAMS, M. H. (1959). Bacteriophages. New York, Interscience.

BerthIAUMe, L. \& ACKeRMANN, H.-W. (1977). La classification des actinophages. Pathologie Biologie 25, 195-201.

BRADLEY, D. E. (1967). Ultrastructure of bacteriophages and bacteriocins. Bacteriological Reviews 31, 230-314.

Brown, N. L. \& SMITH, M. (1977). Cleavage specificity of the restriction endonuclease isolated from Haemophilus gallinarum $(\mathbf{H g a}$ I). Proceedings of the National Academy of Sciences of the United States of America 74, 3213-3216.

Brzezinski, R., Surmacz, E., Kutner, M. \& Piekarowicz, A. (1986). Restriction mapping and close relationship of the DNA of Streptomyces erythraeus phages 121 and SE-5. Journal of General Microbiology 132, 2937-2943.

CHATER, K. F. (1986). Streptomyces phages and their applications to Streptomyces genetics. In The Bacteria, vol. IX, pp. 119-158. Edited by S. W. Queener \& L. E. Day. Orlando: Academic Press.

CoX, K. L. \& BALTZ, R. H. (1984). Restriction of bacteriophage plaque formation in Streptomyces spp. Joumal of Bacteriology 159, 499-504.

Donadio, S., Paladino, R., Costanzi, I., Sparapani, P., Schreil, W. \& IACCARINO, M. (1986). Characterization of bacteriophages infecting Streptomyces erythreus and properties of phage-resistant mutants. Journal of Bacteriology 166, 1055-1060.

Embley, T. M., O'Donnell, A. G., Rostron, J. \& Goodfellow, M. $(1988 a)$. Chemotaxonomy of wall type IV actinomycetes which lack mycolic acids. Journal of General Microbiology 134, 953-960.

Embley, T. M., Smida, J. \& StackebrandT, E. (1988b). Reverse transcriptase sequencing of $16 \mathrm{~S}$ ribosomal RNA from Faenia rectivirgula, Pseudonocardia thermophila and Saccharopolyspora hirsuta, three wall type IV actinomycetes which lack mycolic acids. Journal of General Microbiology 134, 961-966.

Gingeras, T. R. \& Brooks, J. E. (1983). Cloned restriction/ modification system from Pseudomonas aeruginosa. Proceedings of the National Academy of Sciences of the United States of America 80, 402406.

GRUND, A. D. \& Hutchinson, C. R. (1987). Bacteriophages of Saccharopolyspora erythraea. Journal of Bacteriology 169, 3013-3022.

HoPwOOD, D. A. (1988). Towards an understanding of gene switching in Streptomyces, the basis of sporulation and antibiotic production. Proceedings of the Royal Society B235, 121-138.

Hopwood, D. A., BibB, M. J., Chater, K. F., Kieser, T., Burton, C. J., Kieser, H. M., Lydiate, D. J., Smith, C. P., Ward, J. M. \& SCHREMPF, H. (1985). Genetic Manipulation of Streptomyces: a Laboratory Manual. Norwich: The John Innes Foundation.

Katz, L., Chiang, S.-J. D., Tuan, J. S. \& Zaplen, L. B. (1988). Characterization of bacteriophage $\phi \mathrm{C} 69$ of Saccharopolyspora erythraea and demonstration of actinophage propagation by transfection of Streptomyces and Saccharopolyspora. Journal of General Microbiology 134, 1765-1771.

KempF, A., Greiner-MaI, E., Schneider, J., Korn-Wendisch, F. \& KUTZNER, H. J. (1987). A group of actinophages of Faenia rectivirgula. Current Microbiology 15, 283-285. 
LACEY, J. (1987). Nomenclature of Saccharopolyspora erythraea Labeda 1987 and Streptomyces erythraeus (Waksman, 1923) Waksman and Henrichi 1948, and proposals for the alternative epithet Streptomyces labedae sp. nov. International Journal of Systematic Bacteriology 37, 458.

LACEY, J. \& Goodfellow, M. (1975). A novel actinomycete from sugar-cane bagasse: Saccharopolyspora hirsuta gen. et sp. nov. Journal of General Microbiology 88, 75-85.

Lomovskaya, N. D., Chater, K. F. \& Mkrtumian, N. H. (1980). Genetics and molecular biology of Streptomyces bacteriophages. Microbiological Reviews 44, 206-229.

Mandel, M., Schildkraut, C. L. \& Marmur, J. (1968). Use of CsCl density gradient analysis for determining the guanine plus cytosine content of DNA. Methods in Enzymology 12B, 184-195.

Maniatis, T., Fritsch, E. F. \& SambrooK, J. (1982). Molecular Cloning: a Laboratory Manual. Cold Spring Harbor, NY: Cold Spring Harbor Laboratory.

OGATA, S. (1980). Bacteriophage contamination in industrial processes. Biotechnology and Bioengineering 22, 177-193.

Ostrowska-Krysiak, B., Gurkau, M., Sokolowska, B., Sikora, D. \& BLONSKA, A. (1971). New variants of actinophages acting upon Streptomyces erythraeus. Acta Microbiologia Polonica B3, 195-201.

ROBERTS, R. J. (1984). Restriction and modification enzymes.and their recognition sequences. Nucleic Acids Research 12 (supplement), r167-r204.

RoBIN, J. \& RoDRIGUE, A. (1980). Isolation and preliminary characterization of herpes Channel Catfish virus DNA. Canadian Journal of Microbiology 26, 130-134.

SMITH, G. E. \& SUmmers, M. D. (1980). The bidirectional transfer of DNA and RNA to nitrocellulose or diazobenzyloxy methyl paper. Analytical Biochemistry 109, 123-129.

Smorawinska, M., Denis F., Déry, C. V., Magny, P. \& Brzezinski, R. (1988). Characterization of SE-3, a virulent bacteriophage of Saccharopolyspora erythraea. Journal of General Microbiology 134, 1773-1778.

SNYDER, W. C. \& RINEHART, K. L. (1984). Biosynthesis of nargenicin and nodusmicin. Journal of the American Chemical Society 106, 787789.

UlITZUR, S. (1972). Rapid determination of DNA base composition by ultraviolet spectroscopy. Biochimica et Biophysica Acta 272, 1-11.

W AHL, G. M., StERN, M. \& StARK, G. R. (1979). Efficient transfer of large DNA fragments from agarose gels to diazobenzyloxymethyl paper and rapid hybridization by using dextran sulfate. Proceedings of the National Academy of Sciences of the United States of America 76, 3683-3687.

Whaley, H. A., Chidester, C. G., Miszak, S. A. \& Wnuk, R. J. (1980). Nodusmicin: the structure of a new antibiotic. Tetrahedron Letters 21, 3659-3662.

YAMAMOTO, K. R., ALbeRTS, B. M., BenZINGer, R., LAWHORNE, L. \& Treiber, G. (1970). Rapid bacteriophage sedimentation in the presence of polyethylene glycol and its application to large-scale virus purification. Virology 40, 734-744. 